\title{
DIE ONTWIKKELING VAN 'N INSTRUMENT VIR DIE METING VAN DIE KONSTRUK SIELKUNDIGE DIEPTE-ORIËNTASIE
}

\author{
L.C. DE JAGER \\ DEPARTEMENT BEDRYFSIELKUNDE \\ UNIVERSITEIT VAN STELLENBOSCH
}

\begin{abstract}
The development of an instrument (the RD-Depth Questionnaire, Form B) for measuring the construct psychological depth orientation is discussed. Results show that the questionnaire has satisfactory internal consistency and that the items of the questionnaire in general measure the same characteristic. Further research is needed to refine and improve the questionnaire until it meets all the psychometric requirements of a good measuring instrument.
\end{abstract}

Die konstruk sielkundige diepte-oriëntasie is reeds voorheen volledig omskryf en verfyn en aan menslike gedrag in die algemeen gekoppel (De Jager, 1979; 1980).

Aangesien daar tydens die genoemde navorsing nêrens in die literatuur 'n instrument gevind kon word wat die konstruk doeltreffend kan meet nie, moes ' $n$ meetinstrument vir die doel op 'n logiese en rasionele wyse ontwikkel word. Sodanige meetinstrument moes verkieslik die vorm van 'n vraelys aanneem aangesien die konstruk op dié wyse die effektiefste by 'n groot groep toetslinge gemeet kan word. ${ }^{*}$

By die ontwikkeling van die vraelys is daar grootliks gesteun op die konseptuele omlyning van sielkundige diepte-oriëntasie (kyk De Jager, 1979; 1980).

\section{DIE FORMAAT VAN DIE VRAELYS}

Die vraelys moes sodanig wees dat dit relatief maklik aan 'n groot groep persone gelyktydig geadministreer kan word. Verder is besluit dat die vraelys van die meervoudige keuse-tipe moet wees aangesien die meervoudige keusetegniek volgens Anastasi (1961) veral

\footnotetext{
*ersoeke vir afdrukke moet aan die skrywer gerig word .
} 
suksesvol is as dit by selfrapporteervraelyste gebruik word. Hierdie tipe vraelys bied verder die moontlikheid dat sekere spesifieke gedragsituasies as "ankerpunte" vir toetslinge kan dien waarvolgens 'n keuse gemaak kan word.

In die lig van navorsingsresultate oor die optimale aantal punte op ' $n$ beoordelingskaal, is besluit om slegs vier kensketssituasies (ankers) by elke item te gebruik waarvan die toetsling daardie een moet kies wat die beste beskrywing van sy gedrag is. Ankers is so geskryf dat dit 'n kontinuum (skaalwaardes van 1 tot 4) volg wat die mate van sielkundige diepte-oriëntasie verteenwoordig. 'n Waarde van 1 dui op 'n relatief swak diepte-oriëntasie en 4 op 'n relatief goeie diepte-oriëntasie.

Sommige skale is omgeswaai in ' $\mathrm{n}$ poging om bepaalde responsneigings te verminder. Vir hierdie skale moet die keuse van die toetsling van 5 afgetrek word om die korrekte waarde te kry.

'n Individu se telling vir sielkundige diepte-oriëntasie word dus verkry deur sy keuses (skaalwaardes) met betrekking tot die items bymekaar te tel nadat omgeswaaide skale se waardes reggestel is.

\section{PROBLEME VERBONDE AAN DIE MEERVOUDIGE KEUSETEGNIEK}

\section{Formulering van gedragsankers}

Bo-en-behalwe die feit dat dit moeilik is om vir elke item gedragsankers te skryf, is dit nie verseker dat die gedragsketse wat as ankers by die onderskeie items gebruik word beslis verskillende vlakke van die konstruk wat gemeet wil word verteenwoordig nie (Nunnally, 1978). Hierdie probleem is voortdurend in gedagte gehou by die formulering van ankers vir die items in die onderhawige vraelys, in dié sin dat noukeurige aandag gegee is aan semantiese nuanses.

Alhoewel die meervoudige keusetegniek in die vorm van selfrapporteervraelyste sekere psigometriese leemtes toon is verskeie skrywers (Anastasi, 1961; Nunnally, 1978; Scott, 1968; Zavala, 1965) dit eens dat hierdie tegniek een van die bestes is wanneer nie-kognitiewe gedrag gemeet word.

\section{Sosiale aanvaarbaarheid}

Een van die ernstigste punte van kritiek wat teen die selfrapporteertegniek ingebring kan word is die feit dat resultate wat deur middel van so 'n vraelys verkry word dikwels 
gedomineer word deur 'n faktor wat as sosiale aanvaarbaarheid bekend staan (Anastasi, 1961; Nunnally, 1978; Zavala, 1965).

Sosiale aanvaarbaarheid verwys na die neiging om eerder gunstige as ongunstige dinge omtrent jouself te rapporteer. Hierdie neiging gee daartoe aanleiding dat 'n kunsmatig hoë korrelasie tussen sosiale aanvaarbaarheid en itemtellings verkry word (Anastasi, 1961) .

Anastasi (1961) en Scott (1968) beveel aan dat vraelysitems vooraf getoets word vir neutraliteit betreffende sosiale aanvaarbaarheid. Indien die sosiale aanvaarbaarheid van items redelik neutraal gehou kan word, het die selfrapporteertegniek wel meriete as metingstegniek (Anastasi, 1961; Nunnally, 1978; Zavala, 1965).

\section{Semantiese probleme}

Die tweede probleem wat in ag geneem moet word by die gebruik van die selfrapporteertegniek asook die meervoudige keusetegniek is die semantiese probleem. Dit gebeur soms dat die toetsling 'n woord verkeerd verstaan of glad nie die betekenis daarvan ken nie. In sommige gevalle gebeur dit dat die toetsling die basiese doelstelling van die navorser probeer aflei uit die woordgebruik in die vraelys en dan so respondeer soos wat hy dink die navorser wil hê (Nunnally, 1978).

Aangesien die semantiese probleem ook nie sondermeer uit die oog verloor kan word nie, is dit noodsaaklik om vooraf te bepaal watter semantiese probleme toetslinge moontlik kan ondervind wanneer die vraelys voltooi word.

\section{DIE DAARSTELLING VAN 'N ITEMPOEL}

Ooreenkomstig die formaat waarop daar vooraf besluit is, is daar ' $n$ aantal proefitems ontwikkel vir opname in 'n voorlopige vraelys. Hierdie items is op grond van die konseptuele omlyning van die konstruk op 'n logiese en rasionele wyse saamgestel. Itemstamme is so gekies dat dit verskillende areas verteenwoordig. Die volgende aspekte is gedek: Houdings en gewoontes, interpersoonlike verhoudinge, persoonlike kenmerke, eggenoot(e) en kinders, ontspanning, stokperdjies en belangstellings, skool en opvoeding, selfindrukke, waardes, menings, voorkeure en beroep.

Hieronder volg 'n paar van die tipiese proefitems wat in die voorlopige vraelys opgeneem is: 
Wanneer u 'n boot of skip uit die hawe sien wegseil, watter van die volgende kom die naaste aan u waarskynlike ervaring?

1. Sodra dit die kaai verlaat, voel dit of dit finaal deel van 'n ander wêreld is.

2. Solank mens die dreuning hoor, voel dit of die passasiers eintlik maar nog hier rondom jou is.

3. Al het die dreuning reeds verdwyn en al is die beelde nie meer goed te onderskei nie, voel dit asof mens nog tussen die passasiers is.

4. Selfs al is die vaartuig al op die gesigseinder, is dit nie moeilik om jou in te dink as een van die passasiers nie.

Dit is belangrik om 'n kind te leer -

1. Om net na sy ouers te luister omdat hulle die beste ervaring het.

2. Om na sy ouers en alle mense te luister omdat hulle meer lewenservaring het.

3. Om net na mense te luister wat hy/sy weet oor wye ervaring beskik.

4. Om bereid te wees om na enige iemand te luister wat sinvol praat.

As ek die keuse het om enigiets wat ek wil in my vrye tyd te doen sal ek liefs -

1. $\mathrm{Na}$ ' $\mathrm{n}$ sportbyeenkoms gaan, want daar kan ek myself geniet.

2. My algemene kennis opknap en iets aktueel lees.

3. 'n Stuk klere maak of 'n bietjie houtwerk doen.

4. Iets doen waarvan ek baie hou soos byvoorbeeld skilder of iets ontwerp.

\section{DIE VOORLOPIGE VRAELYS}

'n Voorlopige vraelys (die RD-Diepte Vraelys, Vorm A) is saamgestel uit die poel van proefitems. Die vraelys het bestaan uit 61 items wat binne die bestek van 'n lesuur van 40 minute aan 'n groot groep studente geadministreer kon word.

\section{Semantiese en sosiale aanvaarbaarheidsbeoordeling}

Om te verseker dat die items in die voorlopige vraelys neutraal is wat sosiale aanvaarbaarheid betref is die volgende prosedure gevolg:

- Die vraelys is van instruksies rakende aanvaarbaarheidsbeoordeling voorsien en gereed gekry vir toepassing op 'n eksperimentele grondslag; 
- $\quad$ Elke itemvertakking moes deur middel van 'n vyfpunt Likertskaal ten opsigte van sosiale aanvaarbaarheid beoordeel word. Die skaal het gewissel van $1=$ uiters sosiaal onaanvaarbaar tot $5=$ uiters sosiaal aanvaarbaar.

- Langs die sosiale aanvaarbaarheidsbeoordeling is 'n ruimte gelaat waarin die beoordelaar enige onduidelikhede in verband met woorde en begrippe kon aandui .

- $\quad$ Die RD-Diepte Vraelys (Vorm A) is deur 70 buitemuurse studente verbonde aan die Fakulteit Handel en Administrasie van die Universiteit van Stellenbosch beoordeel. Hierdie groep persone is as verteenwoordigend beskou van die groep op wie die vraelys later toegepas sou word. Die studente is vooraf ingelig oor die betekenis van sosiale aanvaarbaarheid en is ook gevra om enige semantiese onduidelikhede aan te teken of mondelings aan die navorser oor te dra. Die instruksies vir die sosiale aanvaarbaarheidsbeoordeling is deur die beoordelaars saam met die navorser deurgelees.

- Die resultate van die beoordelings vir elke itemvertakking is verwerk in 'n gemiddelde beoordeling, standaardafwyking van die beoordeling, maksimum en minimum beoordeling en totale omvang van elke beoordeling. Die resultate van die beoordeling was oor die algemeen gunstig aangesien slegs enkele itemvertakkings uitermate van neutraal afgewyk het. Geen semantiese probleme is ondervind nie.

Itemvertakkings waarvan die gemiddelde beoordeling kleiner as twee of groter as vier was is herskryf met die doel om hulle so neutraal as moontlik te maak wat sosiale aanvaarbaarheid betref.

\section{Itemontleding en betroubaarheidsbepaling van die vraelys}

Nadat die voorafgaande stappe deurgevoer is, is 'n eksperimentele vraelys saamgestel wat aan empiriese toetsing onderwerp is sodat die betroubaarheid daarvan volgens wetenskaplik-erkende prosedures bepaal kon word.

Die vraelys is aan ' $n$ itemontleding onderwerp wat uitgevoer is volgens die voorskrifte van Nunnally (1978) en Anastasi (1961).

Dit het die volgende behels:

- $\quad$ Die RD-Diepte Vraelys (Vorm A) is gedurende 'n lesuur van 40 minute afgeneem by 539 toetslinge wat bestaan het uit handelstudente, studente in chemie, musiek, huishoudkunde en ingenieurswese aan die Universiteit van Stellenbosch. 
- $\quad$ Die volgende stap het die berekening van die korrelasies tussen die afsonderlike items en die totale telling op die vraelys behels.

As eerste stap by die itemontleding van die voorlopige vraelys is (onder andere) die item-totaalkorrelasies van al 61 items asook die betroubaarheidskoëffisiënt (koëffisiënt Alpha) bepaal.

Nunnally (1978) beskou 'n itemtotaalkorrelasie van ,20 en hoër as bevredigend en om hierdie rede is 'n korrelasiekoëffisiënt van ,20 as afsnypunt gebruik sodat alle items met 'n itemtotaalkorrelasie kleiner as ,20 uitgelaat is.

Volgens die voorskrif van Nunnally (1978) is 20 items vervolgens op grond van hulle item-totaalkorrelasies elimineer en die item-totaalkorrelasies asook die betroubaarheidskoëffisiënt vir die oorblywende 41 items bepaal. Uit hierdie 41 items is weer die 20 bestes op grond van hulle item-totaalkorrelasies geselekteer en die betroubaarheidskoëffisiënt bereken. Hierna is 5 items op 'n keer bygevoeg totdat die 41 items wat oorspronklik gekies is, uitgeput was. Die resultate van hierdie itemontledings word in Tabel 1 saamgevat.

TABEL 1

SAMEVATTING VAN RESULTATE VAN DIE ITEMONTLEDING

VAN DIE RD-DIEPTE VRAELYS (VORM A)

\begin{tabular}{lcc}
$\begin{array}{c}\text { Aantal } \\
\text { items }\end{array}$ & $\begin{array}{c}\text { Kleinste } \\
\text { itemtotalkorrelasie }\end{array}$ & $\begin{array}{c}\text { Koëffisiënt } \\
\alpha\end{array}$ \\
\hline 61 &,- 77 &, 631 \\
4. &, 223 &, 720 \\
40 &, 220 &, 718 \\
35 &, 227 &, 710 \\
30 &, 249 &, 705 \\
25 &, 251 &, 683 \\
20 &, 276 &, 646 \\
\hline
\end{tabular}

Vanuit Tabel 1 is dit duidelik dat die 41 beste items 'n instrument met die hoogste betroubaarheidsindeks $(\alpha=, 72)$ lewer. 
Ingeslote by hierdie 41 items was daar drie items waarvan die gemiddelde sosiale aanvaarbaarheidsbeoordelings te hoog of te laag was en is daar besluit om hulle liewer uit die finale vraelys weg te laat.

'n Itemontleding van die oorblywende 38 items asook die betroubaarheidsindeks daarvan word in Tabel 2 aangedui.

TABEL 2

RESULTATE VAN DIE ITEMONTLEDING VAN DIE "BESTE"

38 ITEMS IN DIE OORSPRONKLIKE VRAELYS

\begin{tabular}{|c|c|c|c|}
\hline Item & $\begin{array}{l}\text { Gemiddelde } \\
\text { van item }\end{array}$ & $\begin{array}{l}\text { Standaardafwyking } \\
\text { van item }\end{array}$ & $\begin{array}{l}\text { Item-totaal- } \\
\text { korrelasie }\end{array}$ \\
\hline 1 & 3,182 & 1,015 &, 249 \\
\hline 3 & 2,660 & 1,180 &, 325 \\
\hline 5 & 2,731 &, 904 &, 248 \\
\hline 7 & 2,583 & 1,142 &, 252 \\
\hline 8 & 2,703 & 1,002 & , 409 \\
\hline 10 & 2,788 & 1,042 &, 309 \\
\hline 11 & 3,390 & 1,009 &, 307 \\
\hline 13 & 2,807 & , 939 &, 253 \\
\hline 14 & 3,098 & 1,196 &, 345 \\
\hline 16 & 2,282 &, 881 &, 277 \\
\hline 18 & 2,981 & 1,181 &, 278 \\
\hline 23 & 3,174 & 1,040 &, 328 \\
\hline 24 & 2,258 & 1,261 &, 254 \\
\hline 26 & 3,386 &, 668 &, 345 \\
\hline 27 & 2,620 &, 887 &, 253 \\
\hline 28 & 2,315 & 1,238 &, 322 \\
\hline 30 & 3,224 &, 890 &, 306 \\
\hline 31 & 3,351 & 1,039 &, 265 \\
\hline 33 & 2,898 &, 912 &, 253 \\
\hline 34 & 2,774 &, 982 &, 295 \\
\hline 35 & 2,983 &, 990 &, 359 \\
\hline 37 & 2,677 &, 900 &, 231 \\
\hline
\end{tabular}




\begin{tabular}{cccc}
\hline Item & $\begin{array}{c}\text { Gemiddelde } \\
\text { van item }\end{array}$ & $\begin{array}{c}\text { Standaardafwyking } \\
\text { van item }\end{array}$ & $\begin{array}{c}\text { Item-total- } \\
\text { korrelasie }\end{array}$ \\
\hline 38 & 3,148 &, 711 &, 288 \\
39 & 3,343 &, 783 &, 333 \\
41 & 3,063 &, 749 &, 390 \\
42 & 2,750 &, 822 &, 372 \\
43 & 3,096 &, 735 &, 305 \\
44 & 2,801 &, 741 &, 267 \\
45 & 3,109 &, 772 &, 320 \\
46 & 3,139 & 1,304 &, 259 \\
47 & 2,768 &, 919 &, 285 \\
48 & 3,187 &, 077 &, 291 \\
49 & 3,228 &, 810 &, 283 \\
51 & 2,291 &, 707 &, 262 \\
52 & 3,273 &, 844 &, 311 \\
53 & 2,994 &, 763 &, 252 \\
54 & 3,230 &, 755 &, 214 \\
61 & 3,607 & & \\
\hline
\end{tabular}

Hierdie 38 items is gevolglik gekies om in die finale RD-Diepte Vraelys (Vorm B) opgeneem te word. Soos dit dan ook blyk uit Tabel 2 is koëffisiënt Alpha vir die finale vraelys ,705.

Alhoewel daar verwag sou kon word dat die interne bestendigheid van die vraelys hoër behoort te wees, word 'n betroubaarheidskoëffisiënt van ,71 vir navorsingsdoeleindes as voldoende beskou.

\section{Faktorontleding van die RD-Diepte Vraelys (Vorm A)}

Soos in die voorafgaande gedeeltes uiteengesit is die RD-Diepte Vraelys (Vorm A) op 'n logiese en rasionele wyse saamgestel en empiries getoets. As kruiskontrole van die resultate van die itemontleding is daar besluit om die vraelys aan 'n faktorontleding te onderwerp met die hipotese dat daar 'n relatief suiwer faktorstruktuur aanwesig sal wees. Volgens Nunnally (1967, pp. 255-258) is dit goeie beleid om die faktoriale samestelling van 'n meetinstrument te bepaal nadat dit so goed as moontlik saamgestel is. 
Die 61 items van die RD-Diepte Vraelys (Vorm A) is deur middel van die hoofkomponentmetode faktorontleed en 'n ortogonale rotasie is gebruik. Die matriks van geroteerde faktorbeladings verskyn in Tabel 3.

Uit Tabel 3 blyk dit duidelik dat die RD-Diepte Vraelys nie 'n enkele suiwer faktor meet nie. Dit sou waarskynlik idealisties wees om te verwag dat daar een enkele suiwer faktor aanwesig moet wees, aangesien daar foutvariansie aanwesig is wat onder andere toegeskryf kan word aan sosiale aanvaarbaarheidsverskille tussen die vraelysitems. Alhoewel daar getoets is vir die neutraliteit van items wat sosiale aanvaarbaarheid betref, kan hierdie moontlikheid egter nie uitgesluit word nie.

Daar sou verder ook geredeneer kon word dat daar items aanwesig is wat nie heeltemal logies met die konstruk verband hou nie en dus daartoe aanleiding gee dat daar ongewensde faktore aanwesig is wat die faktorstruktuur van die vraelys uiters kompleks maak. By verdere ontleding moes hierdie moontlikheid in gedagte gehou word en 13 items wat klaarblyklik nie logies verband hou nie is elimineer.

As tweede fase in die faktorontleding van die RD-Diepte Vraelys (Vorm A) is slegs daardie 38 items wat in die finale vraelys opgeneem is aan ' $n$ faktorontleding onderwerp.

Die matriks van geroteerde faktorbeladings van die finale 38 items word in Tabel 4 aangedui. Die gegewens in Tabel 4 toon aan dat alhoewel daar op empiriese sowel as rasioneel-logiese gronde gepoog is om die beste items vir opname in die finale vraelys te selekteer, daar nog steeds nie daarin gelsaag kon word om 'n vraelys saam te stel wat een suiwer faktor meet nie. Dit is op hierdie stadium baie interessante inligting en dit wil voorkom asof diepte-oriëntasie meerfasettig is - 'n moontlikheid wat in latere navorsing ondersoek sal moet word. Hierdie faktore is nie verder ontleed nie aangesien die faktorontleding slegs as kontrolemaatreël (bo en behalwe die itemontleding) ingespan is.

\section{Die samestelling van die finale RD-Diepte Vraelys (Vorm B)}

Op grond van die sosiale aanvaarbaarheidsbeoordeing, die itemontleding en die faktorontleding van die voorlopige vraelys soos in bostaande gedeeltes uiteengesit en gerapporteer is, is die finale vraelys naamlik die RD-Diepte Vraelys (Vorm B) saamgestel. ' $n$ Voorbeeld van die finale vraelys word in Bylaag 1 aangetoon. Hierdie finale vraelys is dan ook gebruik om die konstruk sielkundige diepte-oriëntasie te valideer. 
TABEL 3

MATRIKS VAN ORTOGONAAL GEROTEERDE FAKTORBELADINGS VIR AL

61 ITEMS VAN DIE RD-DIEPTE VRAELYS (VORM A)

(Slegs die hoogste belading vir elke item word aangetoon)

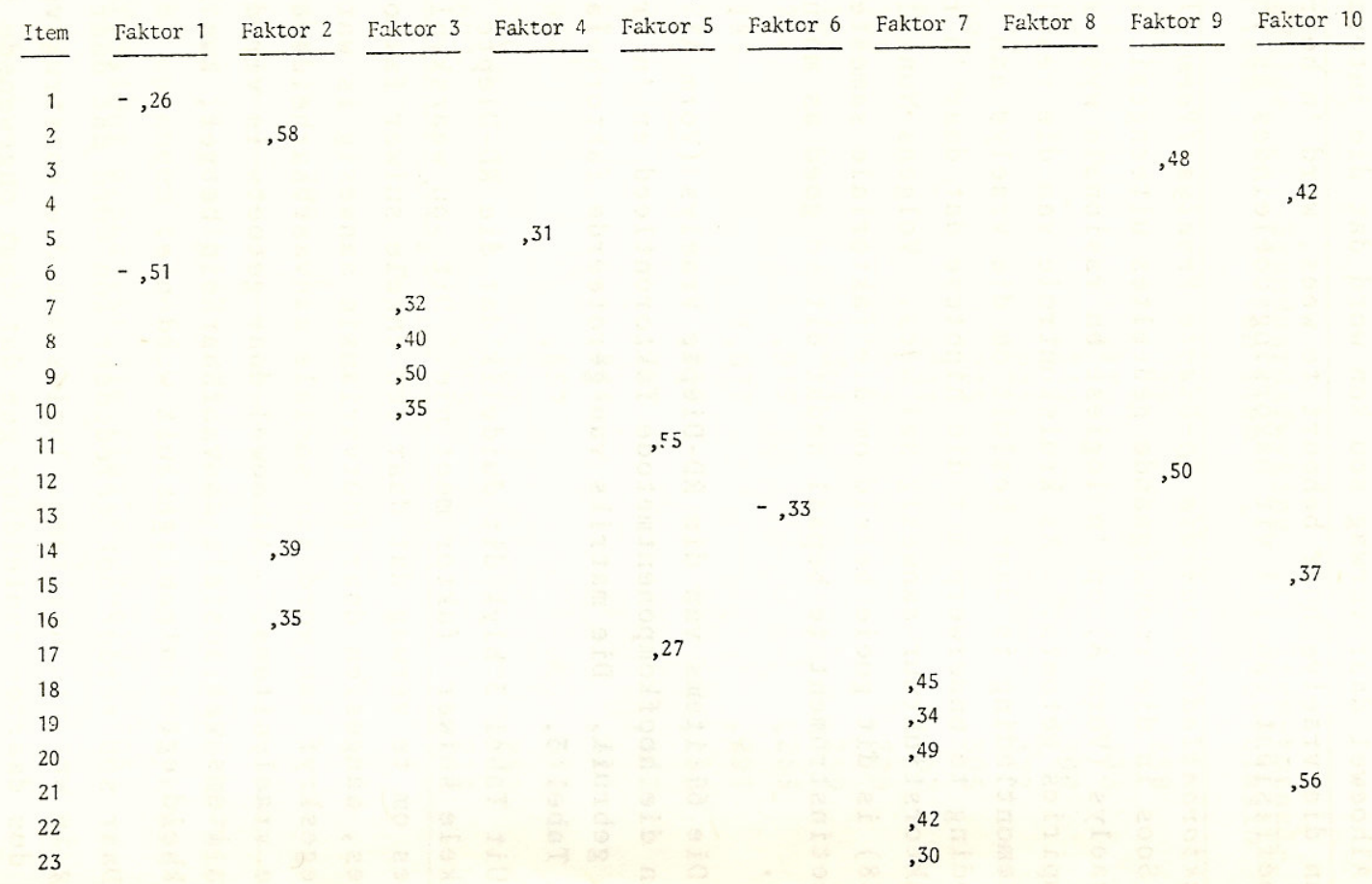

TABEL 3 (Vervolg)

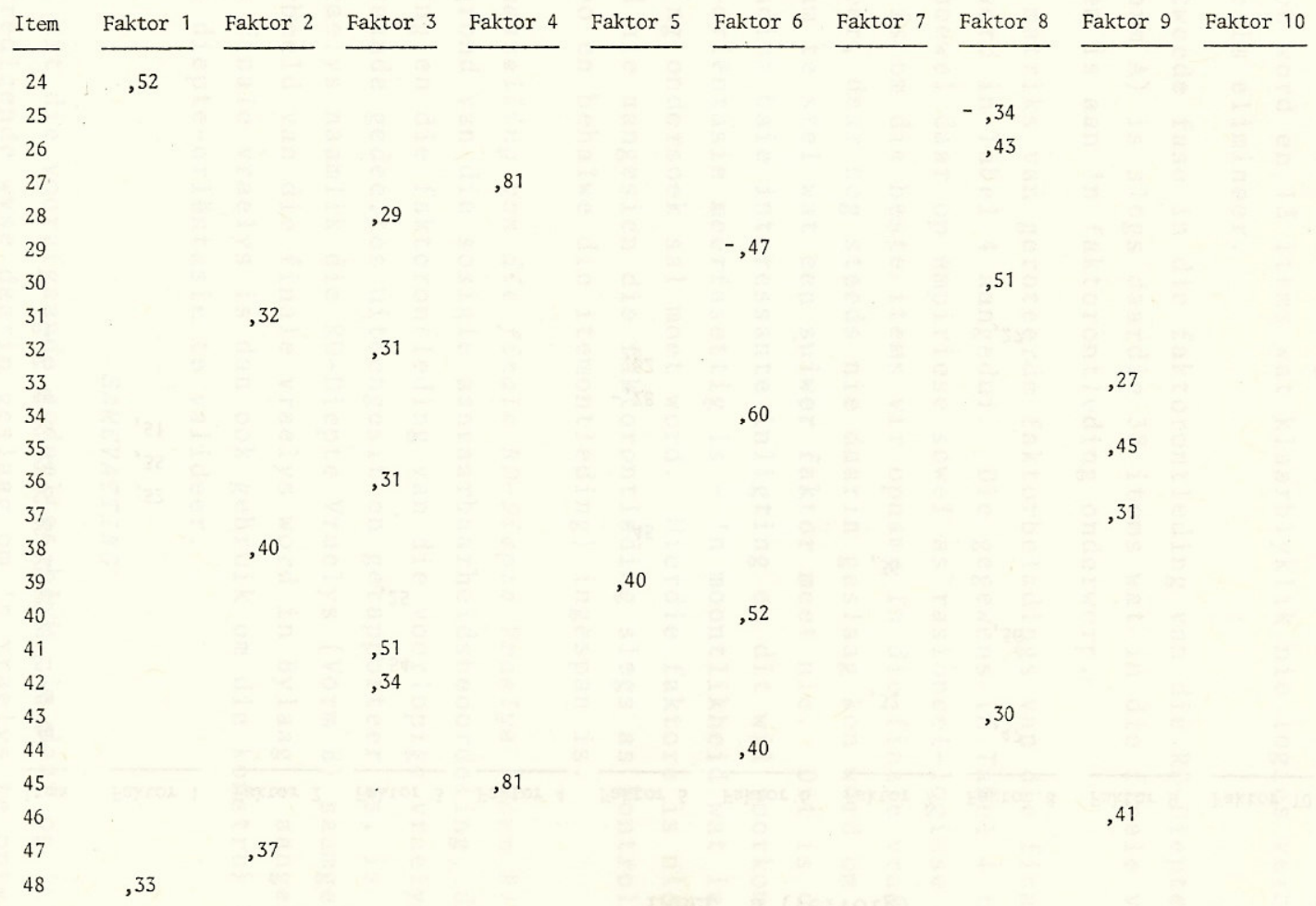




\section{TABEL 3 (Vervolg)}

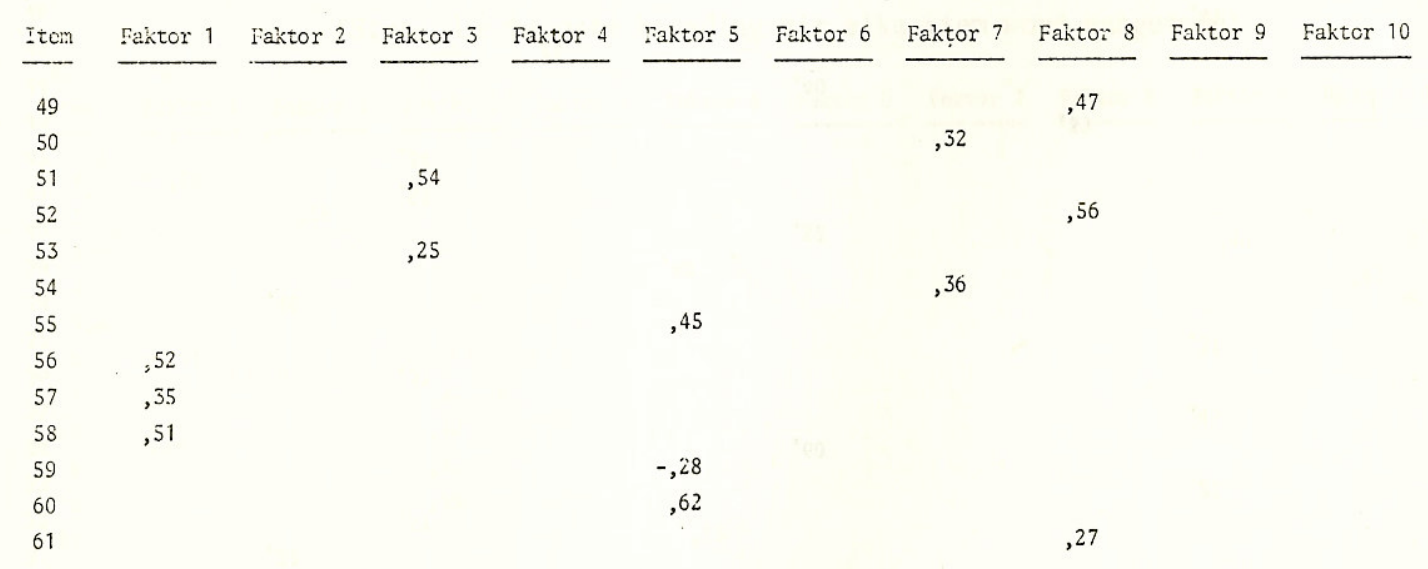

SAMEVATTING

Soos uit die voorafgaande gedeeltes blyk, is daar op " $\mathrm{n}$ redelik bevredigende wyse daarin geslaag om ' $n$ vraelys te ontwikkel wat die konstruk sielkundige diepte-oriëntasie meet. Hierdie vraelys het by empiriese toetsing bevredigende interne bestendigheid getoon en resultate dui daarop dat die items in die vraelys oor die algemeen dieselfde eienskap meet.

Die RD-Diepte Vraelys (Vorm B) kan egter nie as 'n volmaakte instrument vir die meting van sielkundige diepte-oriëntasie gesien word nie en verdere navorsing sal nodig wees om die instrument verder te verfyn sodat dit aan al die psigometriese vereistes van 'n goeie meetinstrument sal voldoen. 
TABEL 4

MATRIKS VAN ORTOGONAAL GEROTEERDE FAKTORBELADINGS VIR DIE "BESTE"

38 ITEMS VAN DIE RD-DIEPTE VRAELYS (VORM A)

(Slegs die hoogste belading vir elke item word aangedui)

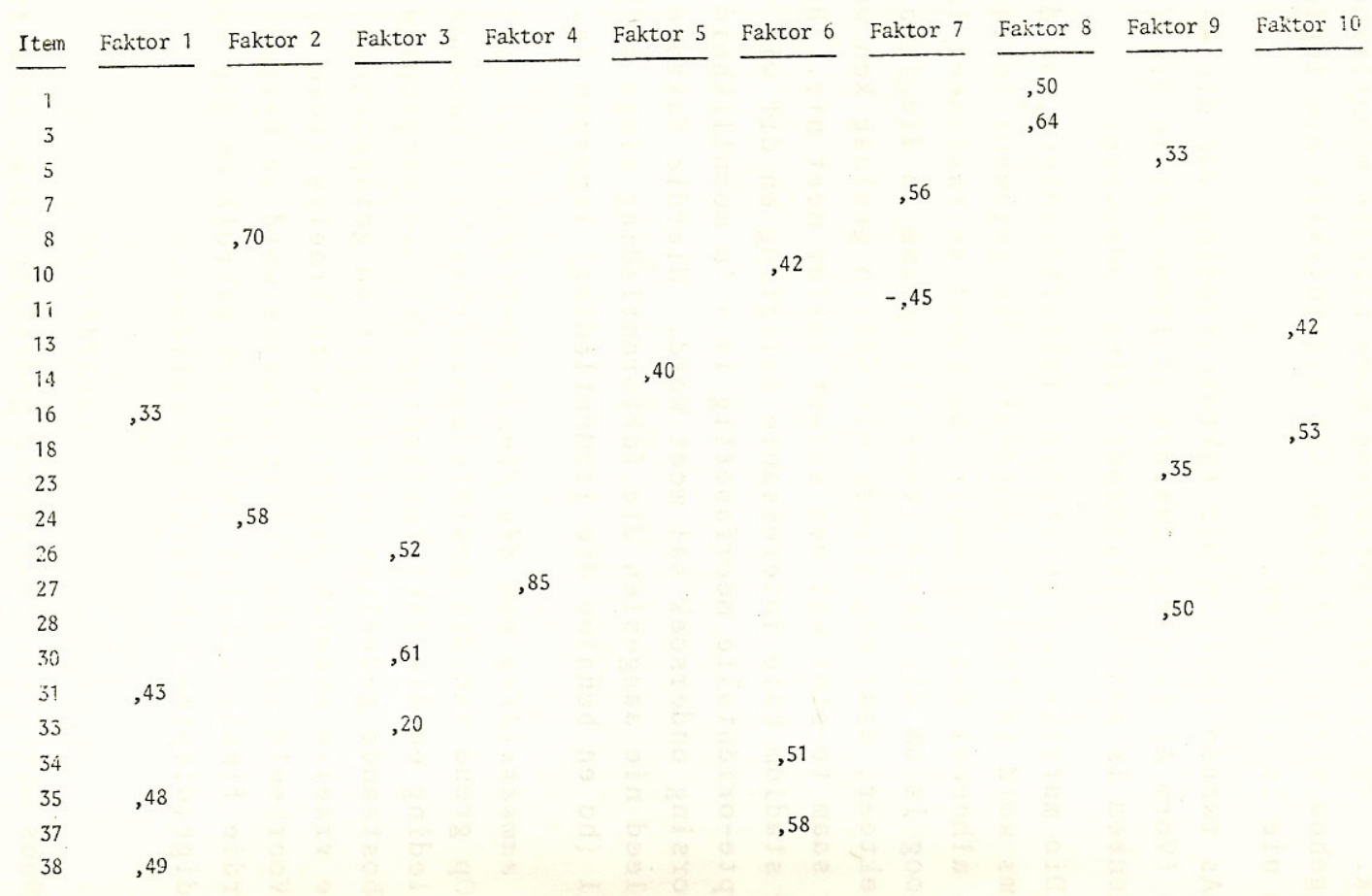

TABEL 4 (Vervolg)

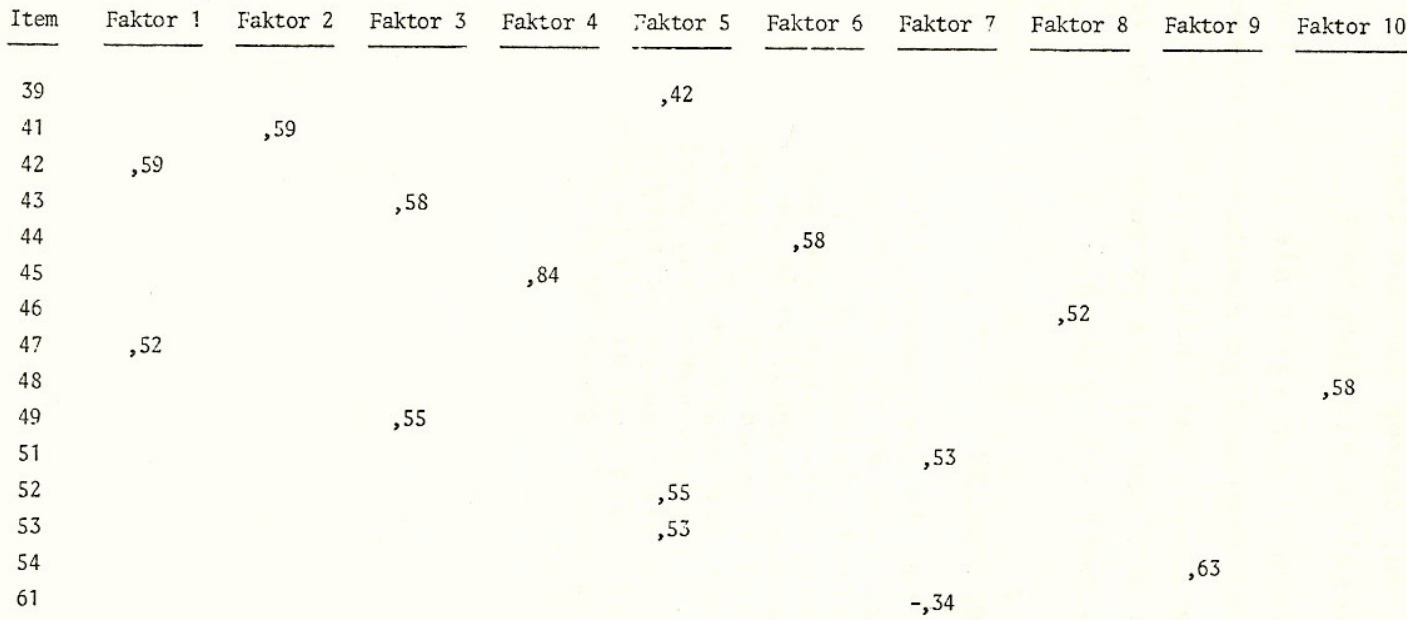




\section{OPSOMMING}

Die ontwikkeling van 'n instrument (die RD-Diepte Vraelys, Vorm B) vir die meting van die konstruk sielkundige diepteoriëntasie word bespreek. Resultate dui daarop dat die vraelys bevredigende interne bestendigheid toon en dat die items van die vraelys oor die algemeen dieselfde eienskap meet. Verdere navorsing word egter nog vereis om die vraelys te verfyn en te verbeter sodat dit aan al die psigometriese vereistes van 'n goeie meetinstrument sal voldoen.

\section{VERWYSINGS}

Anastasi, A. Psychological Testing. New York: MacMillan, 1961.

De Jager, L.C. Sielkundige Diepte-Oriëntasie as Determinant van Menslike Gedrag met Spesifieke Verwysing na die Beroepswêreld. Johannesburg: Ongepubliseerde Doktorale Proefskrif, Randse Afrikaanse Universiteit, 1979.

DeJager, L.C. Sielkundige diepte-oriëntasie: 'n konseptuele omskrywing en verfyning. Perspektiewe in die Bedryfsielkunde, 1980,6(4), 41 - 63.

Nunnally, J.C. Psychometric Theory. New York: McGraw-Hill, 1967.

Nunnally, J.C. Psychometric Theory. New York: McGraw-Hill, 1978.

Scott, W.A. Comparative validities of forced-choice and single stimulus tests. Psychological Bulletin, 1968, 70(4), 231-244.

Zavala, A. Development of the forced-choice rating scale technique. Psychological Bulletin, 1965, 63(2), 117-124. 


\section{BYLAAG 1 \\ RD-DIEPTE VRAELYS (VORM B)}

\section{INSTRUKSIES}

Hierdie vraelys bestaan uit 38 stellings aangaande menslike gedrag. Elke stelling bestaan uit vier alternatiewe. Van u word verwag om op die aparte antwoordvel telkens daardie een alternatief wat die beste beskrywing van u gedrag is te omsirkel. Beantwoord elke stelling so opreg en eerlik as moontlik. U moet asseblief elkeen van die 38 items beantwoord. Indien $\mathrm{u}$ ' $\mathrm{n}$ fout maak, haal die verkeerde keuse met 'n kruis deur en omsirkel dan die regte een.

Moenie te lank talm nie, u eerste reaksie is gewoonlik die akkuraatste. Daar is geen tydsbeperking verbonde aan die beantwoording van die vraelys nie.

By voorbaat dankie vir u samewerking.

1. Wanneer ek rustig sit en koerant lees en ek hoor 'n slag buite -

1. Gaan ek rustig voort met lees, aangesien daar weer iets sal gebeur as dit ernstig was.

2. Gaan ek voort met lees, maar wonder tog wat gebeur het en besluit om later ondersoek te gaan instel.

3. Hou ek onmiddellik op met lees en probeer 'n verklaring gee vir die slag, maar gaan stel eers later ondersoek in na die oorsaak daarvan.

4. Hou ek onmiddellik op met lees, maar soek eers na 'n verklaring vir die slag voordat ek ondersoek na die oorsaak daarvan gaan instel.

*2. Wanneer ek na 'n kalender kyk -

1. Dink ek aan wat ek in besonder nog moet doen en hoedat ek dit tot uitvoer gaan bring.

2. Dink ek aan wat ek in besonder nog moet doen, maar bekommer my nie veel oor hoe ek dit tot uitvoer gaan bring nie.

\footnotetext{
* Skale moet by hierdie items omgeswaai word. 
3. Dink ek in die algemeen aan wat ek nog moet doen en skenk ook terloops aandag aan hoe ek dit gaan doen.

4. Dink ek in die algemeen aan wat ek nog moet doen.

3. Wanneer ek dagdroom is die resultaat daarvan -

1. Sodanig dat dit grens aan wensdenkery wat nooit bewaarheid kan word nie.

2. Sodanig dat dit grens aan wensdenkery, maar wat moontlik ook bewaarheid kan word.

3. Sodanig dat dit realisties is, maar dat dit onwaarskynlik is dat dit wel sal gebeur.

4. Sodanig dat dit amper werklikheid is en dat dit werklik kan plaasvind.

*4. As iemand my in die straat in my tuisdorp of -stad voorkeer en vra hoe om by 'n sekere adres uit te kom -

1. Vind ek dit maklik om aan hom te verduidelik hoe om daar uit te kom, omdat ek nie alleen byna alle straatname onthou nie, maar ook heelwat ander bakens soos geboue, bome, ens. onthou.

2. Vind ek dit betreklik maklik om aan hom te verduidelik hoe om daar uit te kom omdat ek bykans alle straatname ken.

3. Vind ek dit betreklik moeilik, maar slaag ek tog daarin om aan hom te verduidelik hoe om daar uit te kom, omdat ek slegs 'n paar straatname as bakens onthou.

4. Vind ek dit moeilik om aan hom te verduidelik hoe om daar uit te kom omdat ekself nie volgens straatname werk nie.

5. Wanneer ek 'n stokperdjie kies -

1. Kies ek een wat ek bloot sal geniet en wat sal help om ledige uurtjies te verwyl.

2. Kies ek een waarvan ek sal hou, maar waarvan die beoefening 'n geringe mate van vaardigheid vereis.

3. Kies ek een wat stimulerend sal wees en wat sal uitloop op die maak van iets.

4. Kies ek een wat stimulerend is en wat dit vir my moontlik maak om redelik ingewikkelde skeppende werk te doen.

*6. As ek na 'n sketsplan van 'n gebou kyk -

1. Is dit vir my 'n realistiese voorstelling van die gebou en kan ek my baie duidelik voorstel presies hoedat die gebou in sy voltooide vorm gaan lyk. 
2. Is dit vir my 'n twee-dimensionele tekening, maar wat my gewoonlik in staat stel om die derde dimensie te kan visualiseer.

3. Is dit vir my meer as net 'n twee-dimensionele tekening wat in 'n mate vir my 'n beeld gee van wat beoog word.

4. Is dit vir my 'n twee-dimensionele tekening wat slegs aantoon hoedat die verskillende vertrekke aaneenskakel.

7. Wat is die belangrikste oorweging by die keuse van 'n loopbaan?

1. Die mate van geld en status aan die beroep verbonde asook aangename werksomstandighede.

2. Die mate van geld, status en sekuriteit wat aan die beroep verbonde is.

3. Die mate van geld, status en sekuriteit aan die beroep verbonde asook die mate waartoe ' $n$ bydrae tot die welvaart van die mens gemaak kan word.

4. Die mate waartoe 'n mens jou beroep kan beoefen sonder om jou behoefte aan outonomie en sekuriteit prys te gee.

8. As ek 'n groot som geld moet belê -

1. Stel ek belang in die opbrengs van die belegging oor die korttermyn (1 - 2 jaar).

2. Stel ek belang in die sekuriteit van die instansie waar dit belê word en die opbrengs oor die korttermyn (1 - 2 jaar).

3. Stel ek belang in die sekuriteit van die instansie en die opbrengs oor die langertermyn (5 jaar).

4. Stel ek belang in die sekuriteit van die instansie en ook wat die opbrengs van die belegging oor 15 jaar behoort te wees.

*9. Watter van die volgende kenmerke beskryf myself die beste?

1. Skeppend, planmatig, afhanklik, denkend, belangstellend, uitgaande en prestasie georiënteerd.

2. Inskiklik, empaties, aggressief, nadenkend en oorreedbaar.

3. Beperkte toekomsvisie, risikonemend, emosioneel onbetrokke, onbewus van ander se behoeftes en bedeesd.

4. Emosioneel, versigtig, sosiaal onafhanklik en sonder veel ordelikheid. 
10. Watter van die volgende eienskappe het tot nou toe my werkprestasie bevoordeel?

1. Die feit dat ek die werk wat aan my opgedra word volgens voorskrifte doen.

2. Die feit dat ek die werk sover moontlik volgens voorskrif doen, maar dat ek ook vir moontlike afwykings voorsiening maak.

3. Die feit dat ek die werk vooruitbeplan en dan sien wat intussen gebeur sodat ek nie noodwendig volgens voorskrif handel nie.

4. Die feit dat ek 'n opdrag in detail vooruitbeplan en dan handel volgens dit wat beplan is.

*11. In 'n sportwedstryd moet ' $\mathrm{n}$ mens -

1. Jou opponent se volgende stap probeer voorspel en jou handelinge daarvolgens beplan.

2. Jou opponent dophou en sy volgende handeling probeer voorspel en dan te sien wat hy doen voordat jy optree.

3. Jou opponent dophou om te sien wat hy gaan doen sonder om sy handelinge te probeer voorspel, want dit werk nie altyd uit nie.

4. Jou opponent dophou om te sien wat hy gaan doen sodat jy dienooreenkomstig kan optree.

12. As ek iets aan iemand anders moet verkoop -

1. Wys ek hom op die voordele van die produk wat ek wil verkoop en probeer hom op grond daarvan oorreed.

2. Wys ek hom op die voordele van die produk wat ek wil verkoop en toon ook aan waarom dit beter is as ander mededingende produkte.

3. Wys ek hom op die voordele van die produk wat ek wil verkoop en wys terloops daarna dat dit ook saam met ander produkte gebruik kan word.

4. Wys ek hom nie net op die voordele van die produk wat ek wil verkoop nie, maar wys ek hom ook objektief op die nadele van ander mededingende produkte; verder toon ek ook aan hoedat dit saam met ander produkte gebruik kan word.

*13. As ek die keuse het om enigiets wat ek wil in my vrye tyd te doen sal ek liefs -

1. Iets doen waarvan ek baie hou soos byvoorbeeld skilder of iets ontwerp.

2. 'n Stuk klere maak of ' $n$ bietjie houtwerk doen.

3. My algemene kennis opknap en iets aktueel te lees. 
4. Na 'n sportbyeenkoms gaan, want daar kan ek myself uitrus en geniet.

14. Wanneer ek aan 'n sportwedstryd deelneem en ek maak 'n fout -

1. Raak ek kwaad omdat ek voel ek kan die situasie nie hanteer nie.

2. Raak ek kwaad omdat ek 'n fout begaan het en probeer doelbewus om my opponent in 'n lokval te lei sodat hy/sy 'n fout moet maak.

3. Raak ek effens omgekrap, maar probeer om kalm voor te kom en 'n soortgelyke fout te vermy.

4. Aanvaar ek dat ek ook 'n fout kan maak en berus my by die wete dat my opponent ook foute kan maak wat tot my voordeel kan strek.

15. As ek met iemand oor die telefoon gesels -

1. Voel dit vir my of die ander persoon te ver verwyder is en bly die situasie vir my onpersoonlik omdat ek nie met die ander persoon fisies kontak kan maak nie.

2. Alhoewel dit vir my voel of die ander persoon ver verwyder is, kom die situasie nie onpersoonlik en kunsmatig voor nie, maar sal ek tog verkies dat hy/sy persoonlik aanwesig moet wees.

3. Voel dit vir my asof die ander persoon van my verwyder is, maar dit hinder my nie want ek kan myself voorstel hoe hy/sy daar sit en met my gesels.

4. Voel dit vir my of die persoon oorkant my in die stoel sit, want ek kan hom/haar in my geestesoog sien.

*16. As ek die werking van een of ander apparaat aan iemand anders moet verduidelik, sal ek soos volg te werk gaan -

1. Ek verduidelik alle relevante aspekte en hoe hulle met mekaar verband hou.

2. Ek verduidelik aan hom alle aspekte van die apparaat en sy werking wat ek dink vir hom relevant is.

3. Ek verduidelik aan hom alles wat hy sê hy van die apparaat en sy werking moet weet.

4. Ek verduidelik aan hom alles wat ek weet van die apparaat en sy werking.

17. As ek in 'n argument met iemand anders betrokke raak -

1. Voel ek gewoonlik dat alhoewel sy siening van die saak gerespekteer moet word my siening al is wat saak maak. 
2. Voel ek gewoonlik dat alhoewel ek sy siening van die saak behoort te respekteer, ek dit nie kan doen nie want ek kan my nie in sy skoene plaas nie.

3. Voel ek gewoonlik dat sy siening van die saak dalk ook meriete het, maar dan moet ek myself eers in sy skoene plaas.

4. Voel ek gewoonlik dat sy siening van die saak ook reg kan wees want ek kan myself maklik in sy sienswyse en situasie indink.

18. As ek voor die keuse staan om 'n nuwe besigheid te begin sal ek waarskynlik die volgende besluit neem -

1. Om daarmee voort te gaan, want ek is van mening dat wie nie waag nie, wen nie.

2. Om daarmee voort te gaan omdat ek reken die kanse op sukses is gewoonlik redelik goed.

3. Om eers 'n bietjie te wag en te sien wat gebeur, maar ek voel nogtans ek moet 'n kans waag.

4. Om eers rustig oor die aangeleentheid na te dink voordat ek besluit om voort te gaan of nie.

19. Ek dink die hedendaagse jeug kan nie met die ouer geslag regkom nie omdat -

1. Die ouer geslag te nougeset lewe en die ouderdomsgaping dikwels te groot is.

2. Die ouer geslag in ander tye grootgeword het en die moderne samelewing net nie kan aanvaar en verstaan nie.

3. Dat die ouer geslag, alhoewel hulle in ander tye grootgeword het, soms nie die jonger geslag se probleme wil insien nie.

4. Die ouer geslag wel die probleme van die jeug insien, maar dat hulle eintlik niks daaraan doen om hulle aan te pas by moderne tye nie.

*20. As ek 'n vreemdeling ontmoet -

1. Gesels ek gemaklik met hom/haar omdat ek voel ek kan my maklik in sy omstandighede indink en sy gevoelens meeleef.

2. Gesels ek redelik maklik met hom/haar maar voel ek tog dat ek nie myself heeltemal by sy/haar omstandighede kan indink nie.

3. Gesels ek redelik moeilik met hom/haar, maar voel ek tog dat ek later miskien my gevoelens met hom/haar kan deel. 
4. Gesels ek moeilik met hom/haar omdat ek voel hy/sy is te onbekend om my gevoelens met hom/haar te deel.

21. Geld-

1. Ek sien dit as iets waarmee ek so gou as moontlik kan koop wat ek wil hê.

2. Ek spaar dit vír 'n kort tydjie totdat ek iets kry waarop ek dit kan spandeer.

3. Ek spaar dit met die doel om dit te vermeerder sodat ek later meer het om iets mee te koop.

4. Ek hou dit sodat ek op 'n later stadium iets waarvoor ek al lankal beplan kontant kan koop

22. Ek hoor van 'n stamfees van een of ander Swart stam maar ek het nog nooit so 'n fees bygewoon nie. Wat sal waarskynlik my reaksie wees?

1. Dit is vir my onmoontlik om die gebeure by die fees mee te leef omdat dit kultureel te ver van my verwyder is.

2. Alhoewel ek nie vir myself suiwer kan voorstel wat by die fees plaasvind nie, kan ek tog in 'n mate die fees meeleef.

3. Ek kan vir my voorstel wat by die fees gebeur, maar omdat dit binne 'n vreemde kulturele milieu plaasvind, vind ek dit relatief moeilik om alles wat gebeur in my geestesoog te sien.

4. Dit is vir my maklik om myself by die gebeure by die fees in te leef en in my geestesoog te sien wat daar gebeur.

23. As ek 'n mengelmoes van voorwerpe in groepe moet klassifiseer sodat elke groep soortgelyke voorwerpe bevat -

1. Doen ek dit sonder om diep daaroor na te dink en gee ek nie om of 'n klomp daarvan verkeerd geklassifiseer word nie. Spoed is vir my belangriker as akkuraatheid.

2. Is ek in 'n mate versigtig wat ek waar klassifiseer. Dit is vir my belangrik dat ek vinnig werk, maar darem ook nie te veel foute maak nie.

3. Is ek redelik versigtig oor wat ek waar klassifiseer. Dit is vir my belangrik om sover moontlik eers na te dink voordat ek handel, want akkuraatheid en spoed is albei vir my belangrik. 
4. Is ek baie versigtig en dink ek eers mooi na voordat ek die klassifikasie maak. Vir my is akkuraatheid belangriker as spoed.

*24. As ek met 'n ernstige probleem te doen kry -

1. Is dit vir my 'n uitdaging om te probeer om die probleem so goed as moontlik op te los aangesien dit vir my maklik is om myself in te dink in wat kan gebeur as ek dit nie oplos nie.

2. Sal ek die probleem aanpak en dit self probeer oplos as niemand anders die voortou neem nie.

3. Hoop ek daar is iemand anders wat die probleem sal kan oplos omdat ek nie daarvan hou om probleme op te los nie.

4. Los ek die probleem vir iemand anders om op te los en glo ek in elk geval dat die probleem homself mettertyd sal oplos, want dit is vir my moeilik om myself in te dink in wat gaan gebeur as die probleem nie opgelos word nie.

25. As ek die keuse het om enige werk te kies -

1. Sal ek 'n werk kies waarin ek dinge moet doen wat geredelik verstaanbaar is en wat nie veel laste op my plaas nie.

2. Sal ek 'n werk kies wat in die algemeen nie besonder baie vereis nie en waarvan die aard so is dat take met relatief min inspanning uitgevoer kan word.

3. Sal ek 'n werk kies wat soms uitdagend is en waarin ek selde inisiatief moet neem om iets besonders tot stand te bring.

4. Sal ek 'n werk kies wat besonder baie van my vereis en waarin ek soms skeppend moet wees en inisiatief aan die dag moet lê.

*26. As ek moet beplan ten opsigte van my finansiële aangeleenthede oor drie jaar -

1. Voel ek dit is noodsaaklik dat ek beplan, want dit vorm deel van my alledaagse lewe en ek ondervind nie baie probleme om te voorsien wat intussen kan gebeur nie.

2. Voel ek dit is verkieslik dat ek moet beplan, alhoewel dit nog te lank in die toekoms is, maar dat ek darem voorsiening sal moet maak vir dit wat intussen kan gebeur.

3. Voel ek dat dit goed is as ek beplan, maar dat die toekoms in werklikheid duister is en dat baie onvoorsiene dinge kan gebeur. 
4. Voel ek dit is te lank vooruit en ek weet in elk geval nie wat alles intussen gaan gebeur nie - verder voel ek ook ek is nie goed met die soort van ding nie.

27. 'n Kennis het 'n sekere gewoonte waarvan ek nie hou nie -

1. Ek kan glad nie insien waarom hy nie die gewoonte afleer en soos ek optree nie.

2. Ek kan moeilik insien waarom hy die gewoonte moet hê as hy dit netsowel kan afleer en soos ander normale mense kan optree.

3. Sy houding is vir my in 'n mate aanvaarbaar omdat dit hom nie hinder nie, maar ek wens hy wil dit liewer afleer.

4. Ek kan insien dat alle persone nie dieselfde is nie en dat die gewoonte wat hy het hom eintlik uniek maak.

*28. Ek lees in die koerant van 'n gebeurtenis op 'n vreemde plek in 'n ander land -

1. Dit is vir my besonder maklik om die gebeurtenis in perspektief te sien en dit vir my in my geestesoog voor te stel hoedat dit op die vreemde plek lyk.

2. Dit is vir my redelik maklik om sonder inspanning die situasie mee te leef, die gebeurtenis in perspektief te sien en dit vir my voor te stel hoedat dit op die vreemde plek lyk.

3. Dit is vir my redelik moeilik om dit vir my voor te stel hoedat dit op die vreemde plek lyk en die gebeurtenis in perspektief te sien.

4. Dit is vir my uiters moeilik om die gebeurtenis in perspektief te sien en dit vir my voor te stel hoedat dit op die vreemde plek lyk.

29. As ek met iemand anders op 'n ander plek oor die telefoon gesels, voel ek -

1. Ongemaklik omdat hy/sy te ver verwyder is en ek myself nie in sy/haar omstandighede kan indink nie.

2. Effens ongemaklik omdat dit vir my moeilik is om met hom/haar oor 'n afstand op 'n onpersoonlike manier te kommunikeer.

3. Nie juis ongemaklik nie omdat ek met 'n bietjie moeite vir myself kan voorstel hoe sy/haar omstandighede daar uitsien.

4. Voel dit vir my asof hy/sy nie ver verwyder is nie en dat ek myself maklik in sy/haar situasie kan inleef. 
*30. Wanneer ek 'n boek lees -

1. Probeer ek vir myself 'n prentjie skepvan hoe die skrywer lyk en hoe die omgewing lyk waarin hy die boek geskryf het.

2. Stel ek 'n prentjie voor van hoe die skrywer en sy gesin lyk.

3. Stel ek "n prentjie daarvan voor hoe die skrywer en sy huis lyk.

4. Stel ek myself voor hoe die skrywer daarvan lyk.

31. Watter van die volgende benaderings het tot nou toe my werkprestasie bevoordeel?

1. Die feit dat ek die werk so gou as moontlik uitvoer.

2. Die feit dat ek werk afhandel soos wat ek die geleentheid daarvoor het.

3. Die feit dat ek die werk so gou as moontlik en so georganiseerd as moontlik uitvoer.

4. Die feit dat ek die werk so inrig dat daar voorsiening gemaak word vir toekomstige gebeurlikhede wat die uitvoering van 'n taak moontlik kan vertraag.

32. As ek in die aand oor die ligte van 'n stad uitkyk -

1. Probeer ek vasstel waar watter strate en geboue is.

2. Probeer ek vasstel waar watter strate en geboue is, hoe elke uitstaande gebou lyk en wat daarin aan die gang is.

3. Probeer ek strate en geboue identifiseer sonder om ernstig te dink aan die inwoners van die stad.

4. Probeer ek strate en geboue identifiseer en wonder ek ook wat die inwoners van die stad op daardie oomblik doen.

*33. Wanneer iemand in my motor vasry -

1. Probeer ek kalm bly en uitvind waarom die ongeluk gebeur het sonder om hom sondermeer van nalatigheid te beskuldig .

2. Is ek aanvanklik ontstoke, maar bly ek kalm en verneem by hom wat sy verklaring is.

3. Is ek kwaad, en berispe hom oor sy nalatigheid.

4. Is ek onmiddellik briesend en beskuldig ek hom summier van nalatigheid.

34. Ek sien myself as -

1. 'n Persoon wat in baie dinge belangstel, maar relatief min kennis daarvan het. 
2. 'n Persoon wat in baie dinge belangstel, maar graag meer oor elkeen sou wou weet.

3. 'n Persoon wat in verskeie dinge belangstel en heelwat van elkeen weet, maar ek sou tog graag nog meer wil weet.

4. 'n Persoon wat nie net in baie dinge belangstel nie, maar ook oor relatief goeie kennis van bykans alles beskik.

35. In my daaglikse omgang met ander mense -

1. Sien ek hulle as my medemens en is ek nie verder oor hulle bekommerd nie.

2. Sien ek hulle as deel van die samelewing, maar wens ek ek hoef hulle nie in ag te neem nie.

3. Sien ek hulle as interessant, en kan ek dit nie weerstaan om nader met hulle kennis te maak nie.

4. Sien ek hulle as interessante wesens van wie ek graag meer sou wou leer.

*36. Wanneer ek in die straat af stap -

1. Is ek bewus van alles wat ek rondom my hoor en sien en wat rondom my gebeur.

2. Is ek bewus van baie dinge wat rondom my gebeur, maar neem ek slegs 'n beperkte aantal dinge waar.

3. Is ek slegs bewus van wat in my onmiddellike omgewing gebeur en wat ek daarin waarneem.

4. Is ek onbewus van wat rondom my gebeur en konsentreer ek net op waarheen ek stap.

37. Wanneer ek 'n groot groep mense toespreek -

1. Verkies ek om op een persoon (of ander voorwerp) in die lokaal te konsentreer terwyl ek die toespraak maak.

2. Verkies ek om op 'n groepie persone te konsentreer terwyl ek die toespraak maak.

3. Verkies ek om sover moontlik op die hele gehoor te konsentreer terwyl ek praat.

4. Kyk ek na die gehoor en sien hulle as 'n versameling van mense; met ander woorde die gehoor bestaan vir my uit individue.

38. Dit is belangrik om ' $n$ kind te leer -

1. Om net na sy ouers te luister omdat hulle die beste ervaring het. 
2. Om na sy ouers en alle ouer mense te luister omdat hulle meer lewenservaring het.

3. Om net na mense te luister wat hy/sy weet oor wye ervaring beskik.

4. Om bereid te wees om na enige iemand te luister wat betekenisvol praat. 